\title{
Powered Roof Support - Rock Strata Interactions on the Example of an Automated Coal Plough System
}

https://doi.org/10.2478/sgem-2018-0007

received January 6, 2018; accepted March 23, 2018.

Abstract: The study summarises the operating characteristics of the powered roof support (shield) used in an automated plough system. Investigated longwall support units were controlled automatically or by section engineers and positioned in the 'saw tooth' configuration with respect to the longwall face (automatic mode) or linear to the face. Shield pressure data have been analysed in order to identify the impacts of particular factors on the pressure increase profiles. The analysis was supported by the Statistica software to determine the statistical significance of isolated factors. Equations governing the leg pressure at the given time instant were derived and the roof stability factor ' $g$ ' was obtained accordingly, recalling the maximal admissible roof displacement method recommended by the Central Mining Institute (Poland). In the current mining practice, its values are used in monitoring of strata behaviour as indicators of shield-strata interactions, particularly in the context of roof control in longwall mining. It is vital that the method used should be adapted to the actual conditions under which the longwall is operated. In the absence of such adaptations, there will be major discrepancies in results. The conclusions section summarises the current research problems addressed at the Department of Underground Mining, in which the support pressure data in longwall operations are used. The first aspect involves the delineation of deformations of a longwall main gate about $100 \mathrm{~m}$ ahead of the face. The second issue addressed involves the risk assessment of roof rock caving or rock sliding in the tail gate. Another aspect involves the standardisation of local conditions to support the methodology of interpreting shield-strata interactions

\footnotetext{
*Corresponding author: tukasz Herezy, Agh University Of Science And Technology, Faculty Of Mining And Geoengineering, E-mail: Herezy@Agh.Edu.PI

Dariusz Janik, Krzysztof Skrzypkowski: Agh University Of Science And Technology, Faculty Of Mining And Geoengineering
}

in the context of work safety. These methods are being currently verified in situ.

Keywords: rock strata, powered roof support, operating characteristics, monitoring

\section{Introduction}

Upon closure of the Kazimierz Juliusz hard coal mine and abandonment of open-end mining in the Wieczorek hard coal mine, longwall mining now accounts for nearly $100 \%$ of coal mined underground in Poland. Longwall systems are proven and highly effective as long as the appropriate mining machines are selected to be operated under the local geological and mining conditions. The primary consideration is the selection of powered roof support system, and its interactions with the rock strata need constant monitoring. In the Polish hard coal mines, the powered roof supports are selected based on the admissible roof displacement method recommended by the Central Mining Institute. Even though the method was first applied to powered roof sections integrated with shearer and loader systems, it can be well applied to handle powered roof supports interacting with automated coal plough systems. The method relies on the roof stability factor as an indicator of the shield-strata interactions, its value of 0.8 or more implies good roof stability. The actual value of the roof stability factor in the investigated longwall system based on an automated coal plough derived by the method recommended by the Central Mining Institute was found to be similar during the three stages of mining activities: start-up, longwall operation and its termination (about 1.4).

The analysis of powered roof support-strata interactions reveals three distinct ranges in the leg shield pressure (Fig 1):

- $\quad$ set pressure $p_{w}$, achieved at the moment the powered roof support unit is set against the roof. Its value is associated with the supply pressure in the main 
conduit and leak tightness of the hydraulic installation;

- operating pressure $p_{r}$, its value varies in time and is the consequence of static load imposed by the rock strata. This pressure varies between the operating pressure and nominal pressure;

- yield pressure $p_{m}$, it is the maximal pressure handled by the shield leg under the static load. Its value is determined by the opening set pressure (operating pressure) of the relief valve.

In the case of powered roof support operated on longwalls mined with shearer, pressure increase in hydraulic props is attributable to

- load transfer from the subsiding roof;

- increased barred roof area after cutting,

- increased surface area of unsupported roof whilst the neighbouring shield unit is withdrawn and advanced towards the longwall face;

In plough systems, regardless of the actual longwall mining technologies and machines, powered roof support units are positioned either in a linear or in the saw tooth configuration with respect to the longwall face. Depending on their actual arrangement, pressure increase in shield legs follows a different pattern, which is mostly associated with the depth of cut, ranging from 0.01 to $0.25 \mathrm{~m}$ (from 0.65 to $1.2 \mathrm{~m}$ for shearer). Predicted plots of operating pressure $p_{r}$ variations with time for the coal plough support are shown in Figure 2.

Once the shields are set against the roof, pressure increases within the time $t_{1}$ reaching the initial loadbearing capacity $p_{w}$. At that instant, interactions begin between the powered roof supports and the surrounding rock strata. Within the time interval $t_{1}-t_{2}$, rock strata subside over the longwall gallery, causing pressure increase up to the load-bearing capacity $p_{11}$. The rate of increase in operating pressure is not constant; its variations are mainly attributable to

- intensive subsidence within the time interval $t_{1}-t_{2}$, from $p_{w}$ to the operating capacity $p_{1}$;

- reduced roof subsidence rate within the time intervals $t_{2}-t_{3}, t_{4}-t_{5}, t_{6}-t_{7}, t_{8}-t_{9}, t_{10}-t_{11}$;

- increased roof loading after coal cutting by the plough, within time intervals $t_{2}-t_{3}, t_{4}-t_{5}, t_{6}-t_{7} t_{8}-t_{9}, t_{10}-t_{11}$;

- increased surface area of unsupported roof whilst the neighbouring powered roof support is withdrawn and moved towards the face within the time $t_{11}-t_{12}$;

After the moment $t_{12}$, when the maximal operating pressure, $p_{11}$, is achieved, the operation of the yield valve

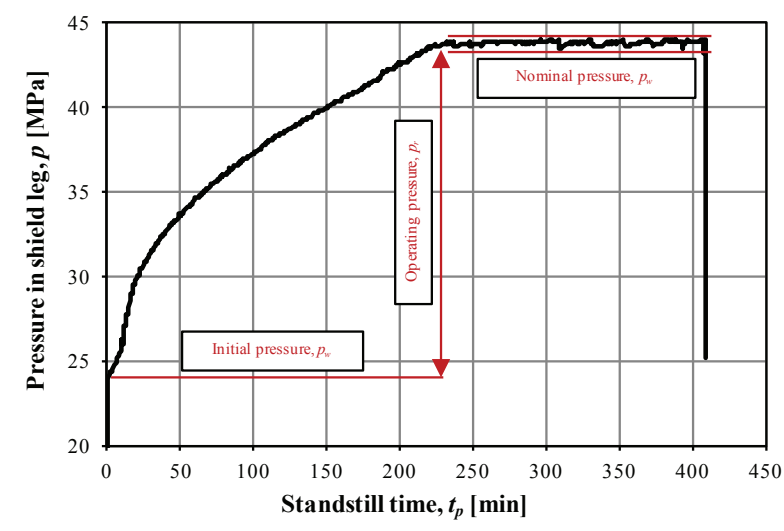

Figure 1: Pressure ranges in the powered supports Source: Author's own sources.

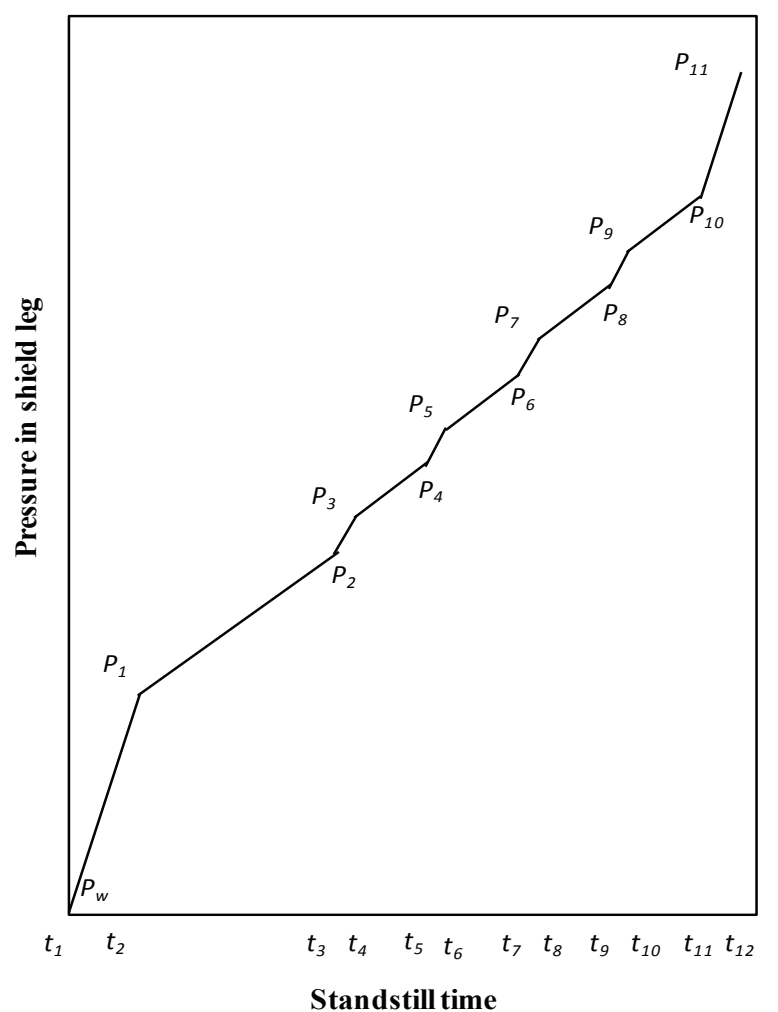

Figure 2: Predicted operating pressure $p_{r}$ of the plough support Source: Author's own sources.

begins or the powered roof support unit is withdrawn and moved towards the longwall face, starting a new load cycle.

Leg pressureand, in consequence, the support capacity are dependent in the first place on roof subsidence over the longwall excavation. This parameter is also referred to as roof convergence over the first meter of the longwall roadways and its actual value is dependent on several 
factors, with its major determinant being the acting load imposed upon the main gate [2]. In caving walls, this load is derived using the formula

$$
Q=n_{q} \cdot n_{a} \cdot \mathrm{h}_{s} \cdot c_{w} \frac{L_{\mathrm{i}}^{1,4}}{0,13 \cdot \mathrm{R}_{\mathrm{c}}^{0,5}+0,7}, \mathrm{MN}
$$

where

$n_{q}$ is the load increase factor;

$n_{a}$ is the destressed strata range factor;

$c_{w}$ is the unit weight of roof strata, $\mathrm{MN} / \mathrm{m}^{3}$;

$h_{s}$ is the reduced height of the longwall face, $\mathrm{m}$;

$L_{1}$ is the span of the longwall face, $\mathrm{m}$;

$R_{c}$ is the compressive strength of roof strata, MPa.

Other determinants are the rate of face advance and pressure acting on the surrounding rock strata $[3,12,13$, 22].

In accordance with the pressure wave theory, the zone of maximal pressure in the rock strata $q_{\max }$ moves towards the longwall face as the rate of face advance $v$ increases. With increasing rate of advance, the maximal pressure in the rock strata goes up to even five times the value of initial pressure [2]. At large mining depths, the value of $q_{\max }$ exceeds the compressive strength $R_{c}$ of the rock strata, causing rock failure. A crack zone emerges ahead of the longwall face, penetrating the coal body at the width of more than $10 \mathrm{~m}$ [2]. The actual width of the cracking zone depends on whether mining operations are continuous or not, when the face advance is often interrupted, the cracking zone will become the widest. When the rate of face advance is uniform, the width of the cracking zone is reduced. In the work [2], the expression governing roof subsidence in the longwall face involves the coefficient $k_{v}$, related to the rate of face advance $v$. In this method, an increase in the face advance rate results in decreased roof subsidence, thus improving the roof stability conditions in the gallery. In the work [3], it was demonstrated that already at some distance from the longwall face, the rock strata tend to move in its direction. These strata movements are attributable to natural and forced separation of the bedded strata. In the consequence of the longwall face displacement alongside the face range at the rate $v$, discontinuities on the rock strata occur beyond the mining impacts zone. The horizontal and vertical distance between the cracking zones from the longwall face depends on the rate of advance $v$ (Fig. 3). The line contouring the sites where the cracking zone begins is roughly shaped like a parabola.

In the consequence, there is a change in pressure in the shield leg. This response is expressed by the bearing

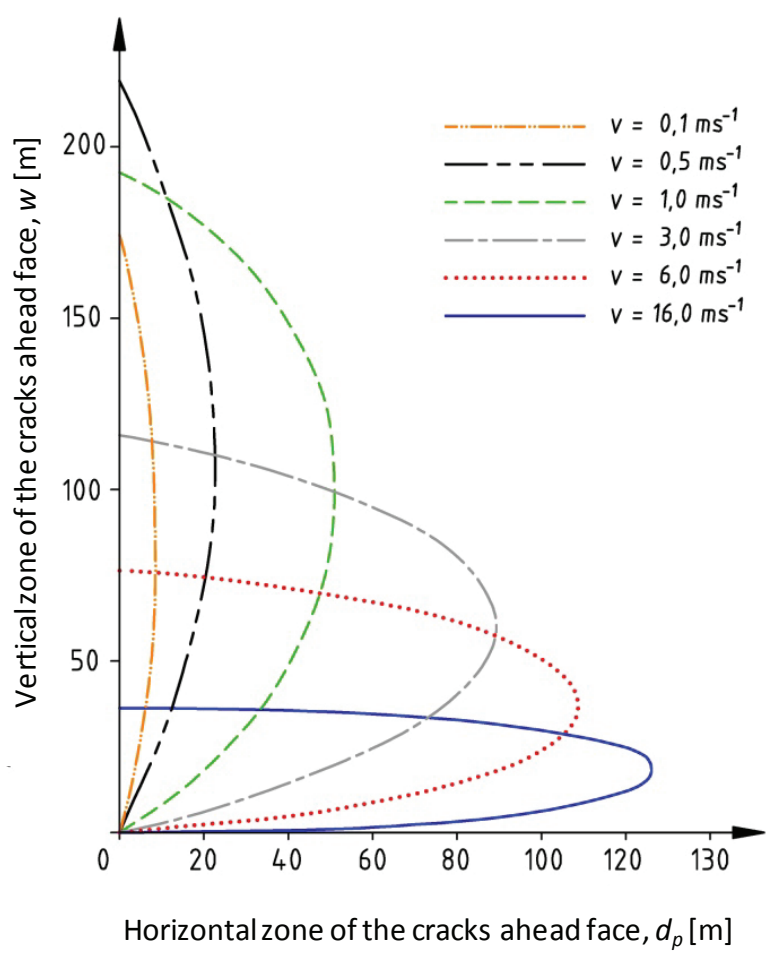

Figure 3: Function governing the formation of the first cracks ahead of an active face.

Source: Based on Drzewiecki 1995.

force [in MN] or the shield capacity [in MPa]. In this study, the shield response to applied load is defined by the pressure $p$ in the space beneath the piston in a shield leg.

One has to bear in mind that when longwall mining systems are used, the shield-strata interactions also involve the human factor, in terms of shield setting quality. In some cases, powered roof supports set by section engineers fail to reach the initial load-bearing capacity $[16,17,19,21]$. As regards the investigated longwall, the powered roof support was manually controlled by section engineers, alongside automatic control systems. When automatic control is implemented, powered roof support units are arranged in the saw tooth configuration with respect to the longwall face, when manually controlled, the powered roof support were in a linear arrangement (Fig 4). In the programme for visualisation of the powered support operation, automatically controlled supports are indicated in purple and those manually controlled are indicated in indigo. The support unit configuration with respect to the longwall face is read off as the length of the divider cylinder in its forth position, designated with blue and yellow colours in Figure 4. A detailed description of the control panel is provided elsewhere [15]. 


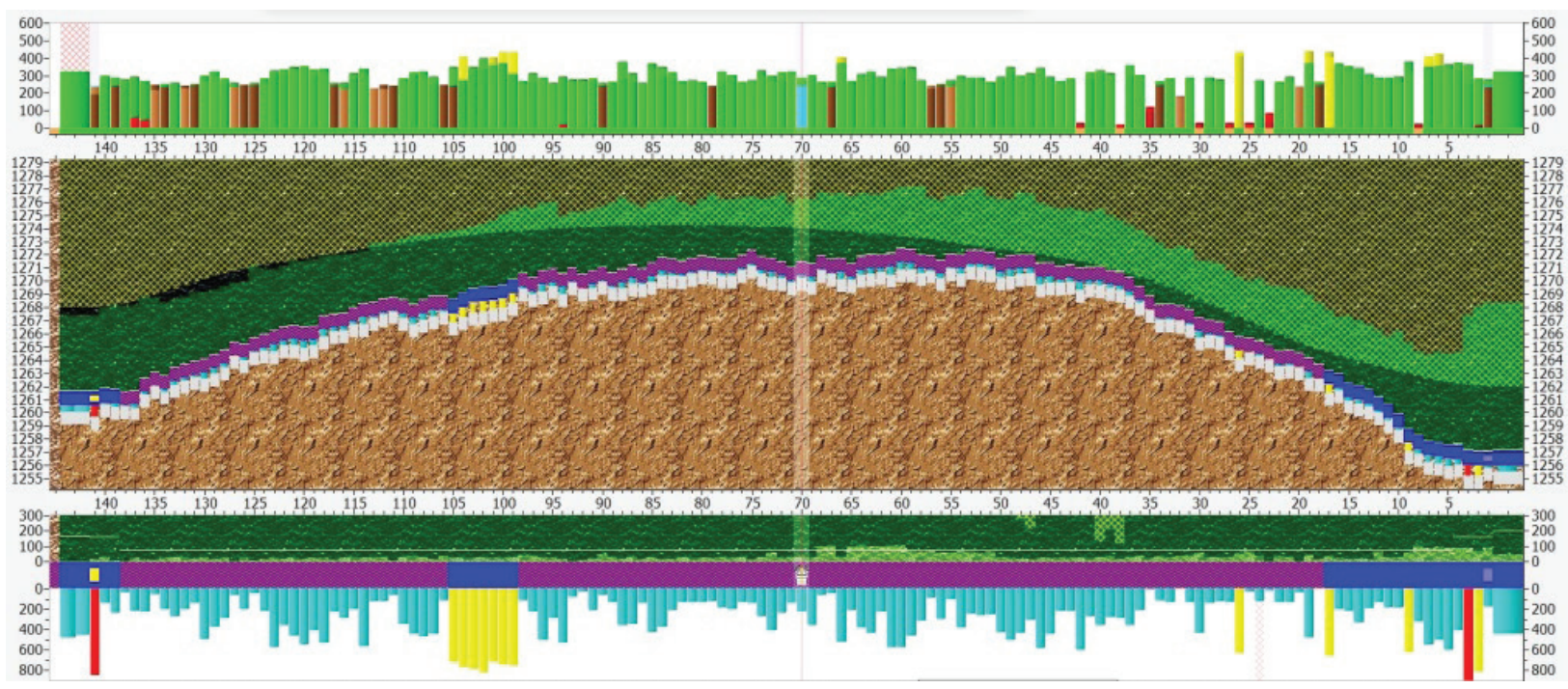

Figure 4: Screenshot from V-Shield.

Source: Author's own sources.

\section{Geological and mining conditions}

The panel considered in this study was nearly horizontal, the seam dip was $2^{\circ}$, the seam thickness varied from 1.33 to $1.8 \mathrm{~m}$ and the average value being $1.6 \mathrm{~m}$. Compressive strength of coal beds fell in the range 12-18 MPa. The longwall face to be operated was $250 \mathrm{~m}$ in width with 1,750 $\mathrm{m}$ along the strike.

The immediate roof in the area comprised claystone, mudstone and sandstone strata. The thickness of the claystone directly above the coal seam ranged from 0.8 to $2.0 \mathrm{~m}$, revealing local occurrence of spherical siderite features. Directly overlying theclaystone was the mudstone bed, with thickness ranging from 0.2 to more than $7 \mathrm{~m}$. The mudstone layer was the thickest in the central part of the face range. Overlying the mudstone was a sandstone bed, up to $7 \mathrm{~m}$ in thickness, also revealing mudstone interlayers. The sandstone bed was the thickest in the front sections of the face range. Overlying the sandstone bed were alternating layers of claystone, mudstone and coal.

In the floor strata, alongside the face range, there was a claystone bed of 0.3-1.5 m in thickness. Underneath are the alternating mudstone, stigmaria mudstone, sandstone and claystone strata, with coal inclusions, revealing the presence of numerous spherical siderite features, particularly in mudstone. No faulting or seismic discontinuities were observed in the area. The operated automated plough system incorporated the following components:
- gliding plough GH 1600 operating in 0.98-2.2 m seam height. The longwall operations uses the version with the lowest plough body height of 0.98-1.23 m;

- face conveyor PF-1032 with a front discharge chute,

- gate-end conveyor PF-1132,

- 141 powered roof supports. From the gateway end, there are 3 units in the opening section, a linear array of 134 and 4 units from the ancillary drive end.

Technical parameters of powered roof support sections are summarised in Table 1.

This longwall site has been studied by other authors who investigated the stability of longwall excavations ahead and behind the longwall face, the operating parameters of the longwall system and the effects of mining parameters on deformation of longwall main gates and rock strata failure $[5,6,7,14,15,20]$.

\section{Operating characteristics of the plough support}

Derivation of relevant shield-strata interaction parameters and their actual values are summarised in works by $[8$, 15]. To better illustrate the operating conditions, plots of leg pressure $p$ are provided for five shield units arranged in a line (Figs. 5 and 6) and their operating parameters dependent on the settings in the control programme V-Shield are compiled in Table 2. 
In the first case shown in Fig 5, only some fraction of supports were automatically controlled and arranged in the saw tooth configuration, for example, the shield section 70 operated in the central part of the longwall face. The remaining shields, arranged in a linear configuration with respect to the longwall face, were manually controlled. Units 8 and 134 were positioned at the distance of $14 \mathrm{~m}$ from the t-junction amongst the longwall face, the main gate and the tailgate. Units 25 and 115 were at the distance

Table 1: Operating parameters of powered roof support (shield) sections.

\begin{tabular}{llll}
\hline Parameters & & Value & Unit \\
\hline Shield height range & $0.95-2.0$ & $\mathrm{~m}$ \\
Operating range & & $1.0-1.9$ & $\mathrm{~m}$ \\
Admissible inclination & Longitudinal & do $15^{\circ}$ & - \\
& Lateral & $\pm 15^{\circ}$ & - \\
Pitch & & 1.75 & $\mathrm{~m}$ \\
Step & & to 0.85 & $\mathrm{~m}$ \\
Number of legs & 2 & $\mathrm{pcs}$. \\
Leg diameter & & $\varnothing 320$ & $\mathrm{~mm}$ \\
Bearing capacity of the leg & Set & 2.573 & $\mathrm{MN}$ \\
& $(32 \mathrm{MPa})$ & & \\
& Yield & 3.619 & $\mathrm{MN}$ \\
(45 MPa) & & $\mathrm{mm}$ \\
Canopy & & 4,030 & $\mathrm{MPa}$ \\
Yield pressure & & 45 & $\mathrm{MPa}$ \\
\hline Supply pressure & & 32 &
\end{tabular}

Source: Author's own sources. of $44 \mathrm{~m}$ from the t-junction. In the second case shown in Figure 6, the powered roof support unit 25 was manually controlled and ranged in the linear configuration whilst the remaining units were automatically controlled and in the saw tooth arrangement. The average compressive strength of roof strata along the face range was $34-40 \mathrm{MPa}$ (Fig. 5) and 30-35 MPa (Fig. 6). The web of coal was varied, ranging from 0.03 to $0.15 \mathrm{~m}$. The rate of face advance was $16 \mathrm{~m} /$ day in the first analysed case and $20 \mathrm{~m} /$ day in the second case. For the two cases considered in the study, the pressure increase contours indicate the moment the coal plough passed beside the given shield (symbolised by black circles). Red circles designate the time instants when the neighbouring shields were withdrawn and moved towards the longwall face.

The analysis of hydraulic leg pressure variations (Figs. 5 and 6) and visualisation of the longwall system operation supported by V-Shield software leads us to the following conclusions:

- In the course of shield setting against the roof, in some cases, both automatically and manually controlled shield legs had too low a set pressure, failing to reach the initial pressure level of $25 \mathrm{MPa}$,

- In supports near the t-junction, the operating pressures registered in shield legs were lower,

- During the 55-min standstill time, neither support unit reached its full nominal capacity,

- The nominal pressure of $42 \mathrm{MPa}$ was reached within 240-260 min following a standstill time period;

- Pressure increase in shield legs after a cut made by the coal plough is registered in some support units only whilst in other units it may be minimal or even non-existent;

- Pressure increase in a shield leg after withdrawing and movement of the neighbouring units can be negligi-

Table 2: Operating parameters of a powered roof support.

\begin{tabular}{|c|c|c|c|c|c|c|c|c|}
\hline \multirow{2}{*}{$\begin{array}{l}\text { Unit } \\
\text { number }\end{array}$} & \multicolumn{4}{|l|}{ Fig. 5} & \multicolumn{4}{|l|}{ Fig. 6} \\
\hline & $\begin{array}{l}\text { Control } \\
\text { system }\end{array}$ & $\begin{array}{l}\text { Shield arrangement with } \\
\text { respect to the longwall } \\
\text { face }\end{array}$ & $\begin{array}{l}\text { Cutting } \\
\text { depth } \\
z \text { [m] }\end{array}$ & $\begin{array}{l}\text { Rate of face } \\
\text { advance } \\
\text { [m/day] }\end{array}$ & $\begin{array}{l}\text { Control } \\
\text { system }\end{array}$ & $\begin{array}{l}\text { Shield arrangement } \\
\text { with respect to the } \\
\text { longwall face }\end{array}$ & $\begin{array}{l}\text { Cutting } \\
\text { depth } \\
z[\mathrm{~m}]\end{array}$ & $\begin{array}{l}\text { Rate of face } \\
\text { advance } \\
\text { [m/day] }\end{array}$ \\
\hline 8 & Manual & Linear & 0.06 & 16.00 & Automatic & Saw tooth & 0.03 & 20.00 \\
\hline 25 & Manual & Linear & 0.05 & & Manual & Linear & 0.05 & \\
\hline 70 & Automatic & Saw tooth & 0.04 & & Automatic & Saw tooth & 0.1 & \\
\hline 115 & Manual & Linear & 0.05 & & Automatic & Saw tooth & 0.15 & \\
\hline 134 & Manual & Linear & 0.05 & & Automatic & Saw tooth & 0.04 & \\
\hline
\end{tabular}




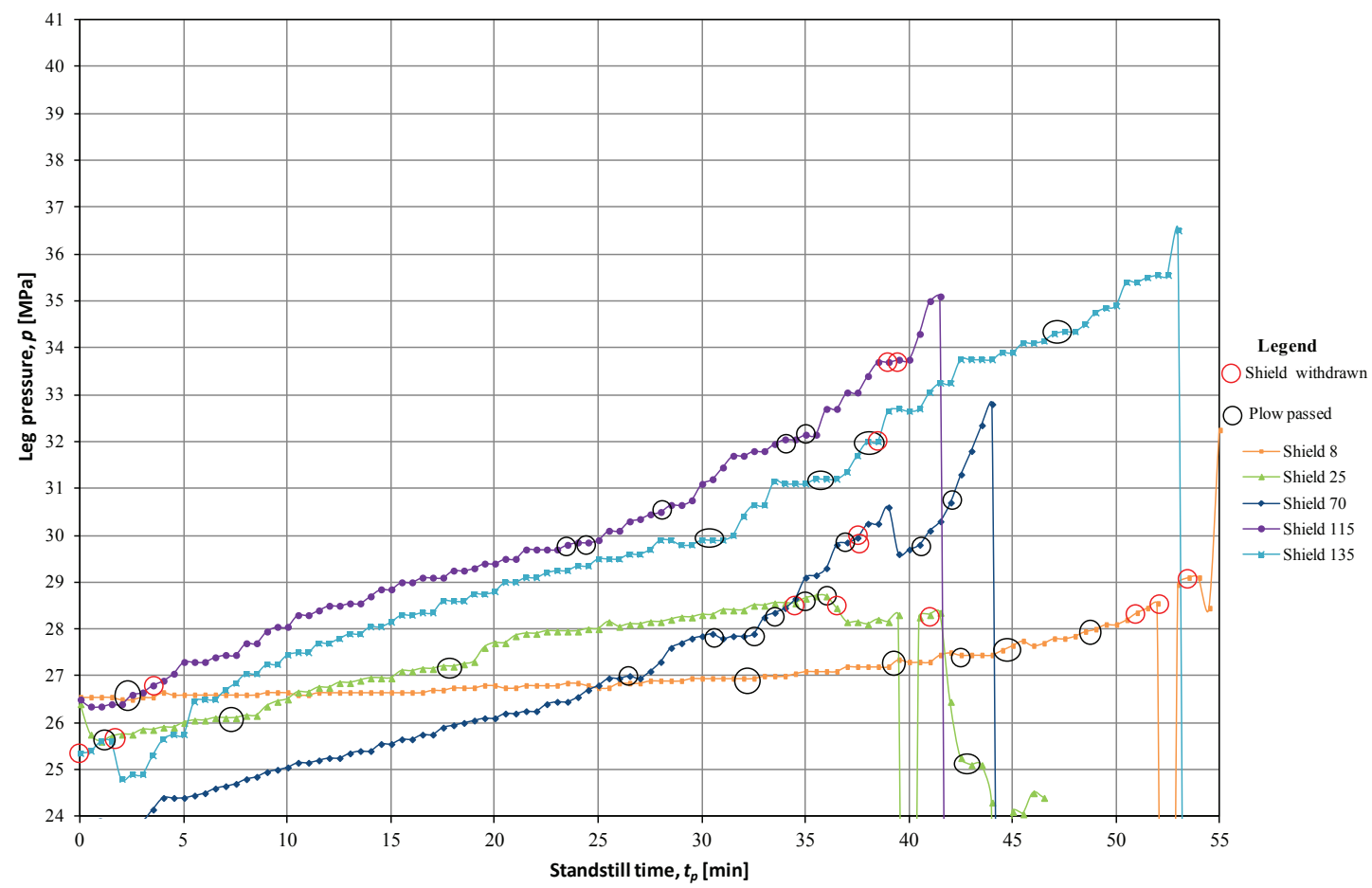

Figure 5: Shield leg pressure variations - case 1.

Source: Author's own sources.

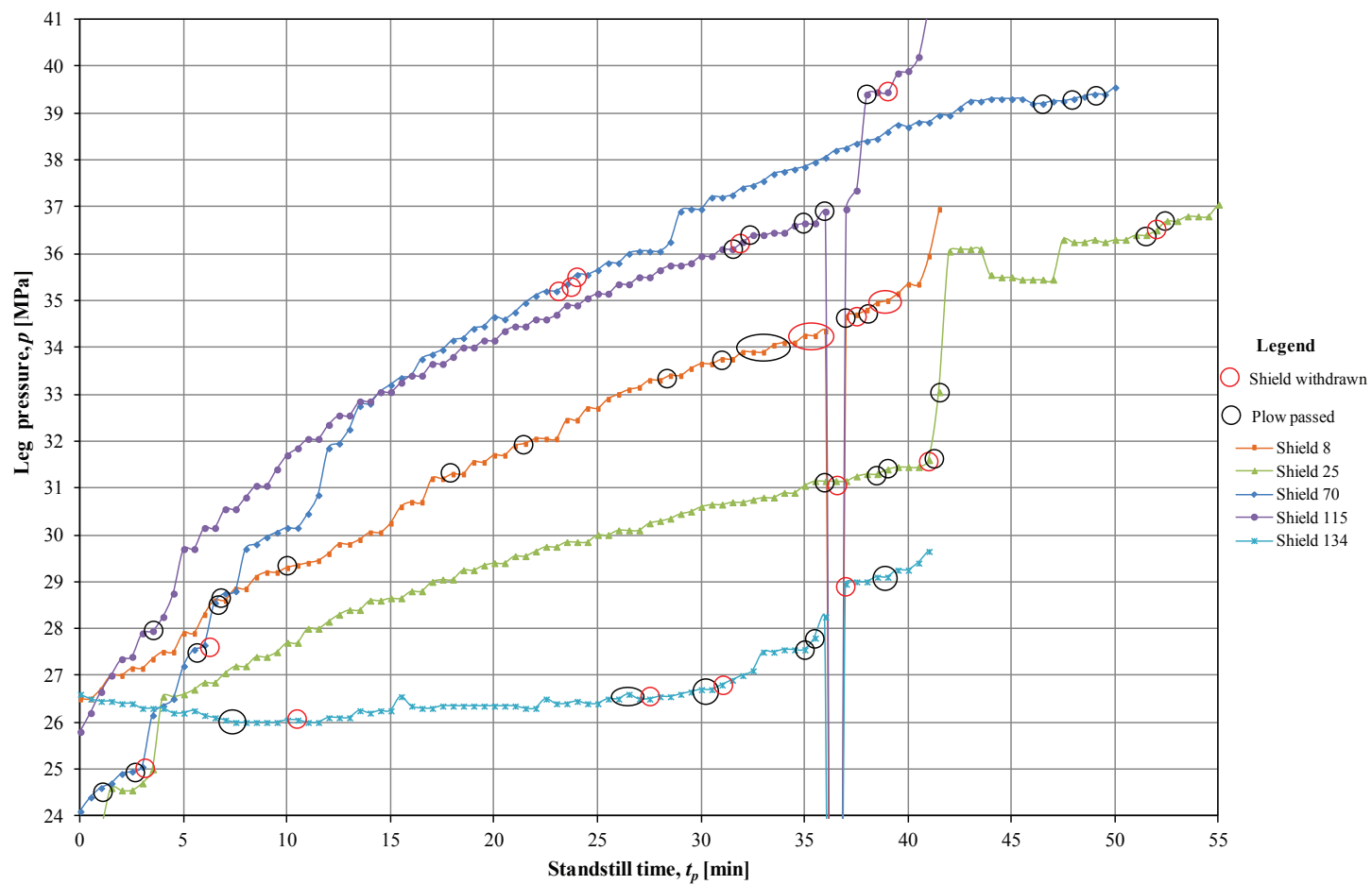

Figure 6: Shield leg pressure variations - case 2.

Source: Author's own sources. 
ble. In happens that after withdrawing and movement of a neighbouring support unit, no pressure increase is registered and when this neighbouring unit is re-set against the roof, the leg pressure can even go down, which is attributable to caving in of the roof strata to the gob area.

- In certain cases, after the supports were withdrawn and re-set against the roof within $30 \mathrm{~s}$, the set leg pressure is reached before the shield withdrawal. It can happen when the roof strata behind the support fail to cave in and the hanging roof bracket imposes extra overloading.

The analysis of leg pressure variations allows for preliminary identification of potential problem areas and taking necessary steps required for more detailed analyses supported by dedicated software. The software Statistica was used to find the function that best captures the features of leg pressure increase in powered roof support units (Equation 2; Fig. 7).

Recalling the exponential equation expressed by formula 2 in the work $[9,15]$, the pressure increase factor $\xi$ is obtained, thus enabling us to predict the deformation of longwall excavations at the distance of $100 \mathrm{~m}$ ahead of the face. The software encapsulates the statistical significance analyses of critical parameters impacting on the support loading (Table 3). These parameters include

- $\quad$ tip to face distance, $d, \mathrm{~m}$,

- rate of face advance $v, \mathrm{~m} /$ day,

- compressive strength of roof strata $R_{c}, \mathrm{MPa}$,

- standstill time $t_{p}$, min,

$$
p(t)=a \cdot\left(1+\exp ^{\left(-\frac{b}{t}\right)}\right)
$$

where

$p$ is the average leg pressure in support legs, MPa, $t$ is the time of pressure increase, $\min$,

$a$ is the coefficient, MPa.min,

$b$ - coefficient, $\min$.

For the first two models in which $t_{p} \leq 30$ min and $t_{p} \leq 60$ $\mathrm{min}$, all factors are found to be statistically significant; as regards the third model in which $t_{p} \leq 250 \mathrm{~min}$, two factors appears to be insignificant: barred roof area and compressive strength of roof rock strata.

Statistical data yield Equations 3-5 governing the shield leg pressure for the adopted criteria and for the geological and mining conditions under which the longwall is being operated.

Equation expressing the predicted leg pressure within the time interval $t_{p}=0-30 \mathrm{~min}$ :

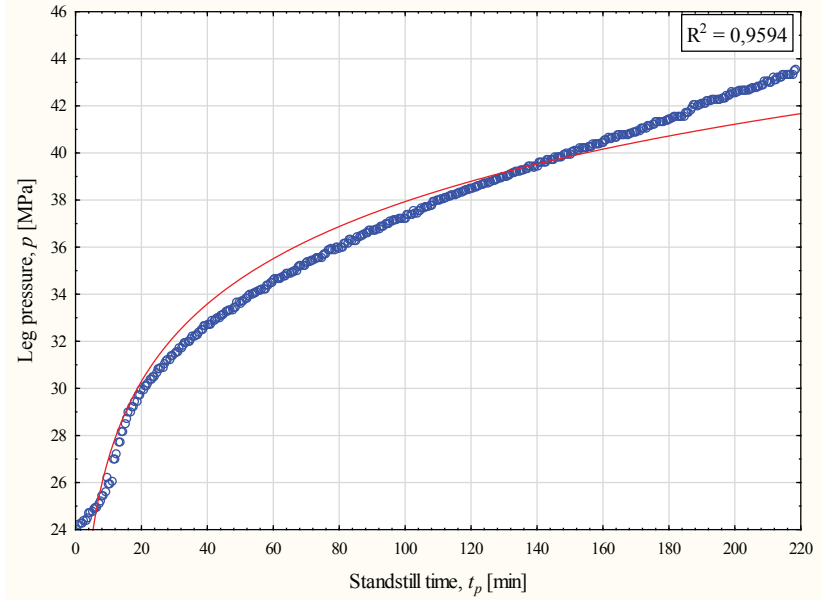

Figure 7: Correlating the real pressure increase in a leg with that predicted based on an exponential function.

Source: Author's own sources.

$$
p=24.62+6.75 d+0.20 v-0.06 R_{c}+0.10 t_{p}
$$

Equation expressing the predicted leg pressure within the time interval $t_{p}=0-60 \mathrm{~min}$ :

$$
p=25.13+7.07 d+0.02 v-0.08 R_{c}+0.08 t_{p}
$$

Equation expressing the predicted leg pressure within the time interval $t_{p}=0-250 \mathrm{~min}$ :

$$
p=24.80+0.28 v+0.02 t_{p}
$$

The roof stability factor ' $g$ ' can thus be determined, based on these equations and the maximal roof displacement method recommended by the Central Mining Institute. The work [10] summarises the results of statistical analysis of the support performance under the geological and mining conditions considered in this study and provides the procedure for predicting the roof stability factor ' $g$ ' assuming that the pressure $p$ should be interpreted as load imposed by the roof strata. Thus obtained values of ' $g$ ' are in the range $0.84-0.95$, indicative of good shieldstrata interactions. However, the predicted values are less by about $0.56-0.45$ than those obtained by the method recommended by the Central Mining Institute. This difference is attributable to time-variant roof loading and this aspect is encapsulated in Equation 3-5 and in the work by [10], whilst the method recommended by Central Mining Institute does not consider it. 
Table 3: Statistical significance of model parameters.

\begin{tabular}{|c|c|c|c|c|c|c|c|c|c|c|}
\hline \multirow[t]{2}{*}{ Effect } & \multicolumn{10}{|c|}{$\begin{array}{l}\text { Parameter evaluation: } z \text { sigma parameterisation with constraints } \\
\text { Acceptance condition: } p_{\min } \geq 24 \mathrm{MPa}, \mathrm{p}_{\max } \leq 42 \mathrm{MPa}, \mathrm{t}_{\mathrm{p}} \leq 30 \mathrm{~min}\end{array}$} \\
\hline & $\begin{array}{l}\text { Leg pressure } \\
\text { factor }\end{array}$ & $\begin{array}{l}\text { Leg pre } \\
\text { ssure, } \\
\text { Standard } \\
\text { error }\end{array}$ & $\begin{array}{l}\text { Leg pre } \\
\text { ssure, } \\
\text { t-value }\end{array}$ & $\begin{array}{l}\text { Leg pre } \\
\text { ssure, } \\
\text { p-value }\end{array}$ & $\begin{array}{l}-95,00 \% \\
\text { Confide. } \\
\text { Interval }\end{array}$ & $\begin{array}{l}+95,00 \% \\
\text { Confide. } \\
\text { Interval }\end{array}$ & $\begin{array}{l}\text { Leg pre } \\
\text { ssure, } \\
\text { Beta }(\beta)\end{array}$ & $\begin{array}{l}\text { Leg } \\
\text { pressure, } \\
\text { Error beta } \\
(\beta)\end{array}$ & $\begin{array}{l}-95,00 \% \\
\text { Confide. } \\
\text { Interval }\end{array}$ & $\begin{array}{l}+95,00 \% \\
\text { Confide. } \\
\text { Interval }\end{array}$ \\
\hline Free term & 24.61 & 0.12 & 195.92 & 0.00 & 24.37 & 24.86 & & & & \\
\hline $\begin{array}{l}\text { Roof barring } \\
\text { factor }\end{array}$ & 6.75 & 0.09 & 77.65 & 0.00 & 6.58 & 6.92 & 0.31 & 0.004 & 0.30 & 0.32 \\
\hline $\begin{array}{l}\text { Rate of face } \\
\text { advance factor }\end{array}$ & 0.02 & 0.003 & 5.89 & 0.00 & 0.01 & 0.02 & 0.02 & 0.01 & 0.01 & 0.02 \\
\hline $\begin{array}{l}\text { Compressive } \\
\text { strength of } \\
\text { roof strata } \\
\text { factor }\end{array}$ & -0.06 & 0.01 & -18.91 & 0.00 & -0.06 & -0.05 & -0.06 & 0.01 & -0.07 & -0.06 \\
\hline $\begin{array}{l}\text { Standstill time } \\
\text { of a support } \\
\text { unit factor }\end{array}$ & 0.09 & 0.01 & 69.92 & 0.00 & 0.09 & 0.09 & 0.28 & 0.01 & 0.27 & 0.28 \\
\hline \multicolumn{11}{|c|}{$\begin{array}{l}\text { Parameter evaluation: } z \text { sigma parameterisation with constraints } \\
\text { Acceptance condition:: } p_{\min } \geq 24 \mathrm{MPa}, \mathrm{p}_{\max } \leq 42 \mathrm{MPa}, \mathrm{t}_{\mathrm{p}} \leq 60 \mathrm{~min}\end{array}$} \\
\hline Free term & 25.13 & 0.11 & 213.21 & 0.00 & 24.90 & 25.36 & & & & \\
\hline $\begin{array}{l}\text { Roof barring } \\
\text { factor }\end{array}$ & 7.07 & 0.07 & 93.72 & 0.00 & 6.92 & 7.21 & 0.31 & 0.01 & 0.30 & 0.32 \\
\hline $\begin{array}{l}\text { Rate of face } \\
\text { advance factor }\end{array}$ & 0.01 & 0.01 & 5.59 & 0.00 & 0.01 & 0.02 & 0.01 & 0.01 & 0.01 & 0.02 \\
\hline $\begin{array}{l}\text { Compressive } \\
\text { strength of } \\
\text { roof strata } \\
\text { factor }\end{array}$ & -0.07 & 0.01 & -25.44 & 0.00 & -0.08 & -0.07 & -0.08 & 0.01 & -0.08 & -0.07 \\
\hline $\begin{array}{l}\text { Standstill time } \\
\text { of a support } \\
\text { unit factor }\end{array}$ & 0.07 & 0.00 & 103.10 & 0.00 & 0.07 & 0.07 & 0.34 & 0.01 & 0.34 & 0.35 \\
\hline \multicolumn{11}{|c|}{$\begin{array}{l}\text { Parameter evaluation: } z \text { sigma parameterisation with constraints } \\
\text { Acceptance condition:: } p_{\min } \geq 24 \mathrm{MPa}, \mathrm{p}_{\max } \leq 42 \mathrm{MPa}, \mathrm{t}_{\mathrm{p}} \leq 250 \mathrm{~min}\end{array}$} \\
\hline Free term & 24.79 & 2.89 & 8.56 & 0.00 & 19.08 & 30.51 & & & & \\
\hline $\begin{array}{l}\text { Roof barring } \\
\text { factor }\end{array}$ & -0.09 & 3.23 & -0.03 & 0.97 & -6.48 & 6.28 & -0.01 & 0.07 & -0.14 & 0.14 \\
\hline $\begin{array}{l}\text { Rate of face } \\
\text { advance factor }\end{array}$ & 0.28 & 0.05 & 4.98 & 0.00 & 0.17 & 0.39 & 0.35 & 0.07 & 0.21 & 0.48 \\
\hline $\begin{array}{l}\text { Compressive } \\
\text { strength of } \\
\text { roof strata } \\
\text { factor }\end{array}$ & 0.11 & 0.06 & 1.69 & 0.09 & -0.02 & 0.23 & 0.12 & 0.07 & -0.02 & 0.27 \\
\hline $\begin{array}{l}\text { Standstill time } \\
\text { of a support } \\
\text { unit factor }\end{array}$ & 0.02 & 0.01 & 4.21 & 0.00 & 0.01 & 0.03 & 0.32 & 0.07 & 0.17 & 0.47 \\
\hline
\end{tabular}

Source: Author's own sources. 


\section{Conclusions}

Unsupported by advanced computer techniques, studies investigating the longwall support and roof strata interactions or the support unit performance would rely on time-consuming and cumbersome procedures, whilst the collected data fail to capture the conditions in the entire longwall region, focusing only on its sections. The state-of the-art control, monitoring and visualisation technologies applied in automated longwall systems, including coal plough systems [4], enable the entire panel to be investigated, taking into account varied geological and mining conditions. There is a large quantity of collected data to be handled (e.g. one file of readouts registered within one time instant in the V-Shield programme amounts to 60,000 data cells), which further complicates data interpretation and elimination of redundant data that may negatively impact on reliability of final results. Another issue to be addressed involves the actual selection of the methodology. On the basis of the results of analyses and their interpretations, the load cycle analysis can now be used in real-life applications, to improve the work safety in mines.

Researchers from the Department of Underground Mining AGH-UST investigating interactions between longwall roof-powered support and roof strata assumed that the longwall system with the dedicated software is to be treated as a research tool. Data collected from the longwall system are used in the development of new methods to enhance the monitoring of the rock strata behaviour in the vicinity of the longwall site. Recalling the vast body of expertise reported in the works by $[1,2,11,18$, $23,24,25,26,27]$, AGH researchers have now focused on the following aspects:

- the potential to predict the deformations of longwall excavations. First results are summarised in the work by [15], presenting a new methodology to obtain the pressure increase factor $\xi$ correlating the vertical convergence of a longwall face with the shield leg pressure increase profiles. The actual value of the pressure increase factor identifies the potential of enhanced deformations, which hinders the regular longwall operations. The method is still evolving $[8,9]$ and dedicated software is being developed to support the verification process in situ;

- the potential of early diagnosis of rock sliding and caving in of roof strata in longwall sites. To date, algorithms that support the rock fall hazard predictions have been developed. Alongside the user interface, these algorithms are now being tested in the in situ conditions in one hard coal mine;
- developing a reliable methodology for the description of coal plough system performance and shield strata interactions to ensure safe longwall operations under the local geological and mining conditions. Some aspects of the involved research work are summarised in this article.

The leg pressure increase is dependent on several factors and therefore displays a wide variability range. Isolation of the many interconnected factors and quantification of their impacts is based on the interpretation of statistical parameters, depending on accurate delineation of the strata behaviour under the given geological and mining conditions. Correlation of theoretical knowledge with engineering expertise allows for making full use of a powerful research tool - the automated coal plough system.

Analyses reported in this study revealed that the algorithm used in the methodology for predicting roof support-strata behaviour during the coal plough operations ought to contain a variable expressing the plough position with respect to the investigated support.

For the effective use of a coal plough system as a research tool, a vast body of expertise gathered to date and a large quantity of data from the plough system monitoring encourage the further development of concepts and methods aimed to improve work safety and effectiveness of longwall mining operations.

\section{References}

[1] Barczak T. M., Esterhuizen G. S., Ellenberger J., Zahng P., A first step in developing standing roof support design criteria based on ground reaction data for Pittsburgh seam longwall tailgate support. 27th International conference on ground control in mining, Morgantown, West Virginia, 2008.

[2] Biliński A., Metoda doboru obudowy ścianowych wyrobisk wybierkowych i chodnikowych do warunków pola eksploatacyjnego. Prace naukowe - monografie CMG Komag, Gliwice, 2005.

[3] Drzewiecki J., Mechanizm powstawania rozwarstwień mocnych skat stropowych w świetle pomiarów in situ. Katowice, Prace Naukowe GiG, 1995.

[4] Dziura J., Kompleks „Mikrus” - nowa technologia wybierania pokładów cienkich. Wiadomości górnicze, nr 4, 2013.

[5] Herezy t., Ksztattowanie się zasięgu strefy spękań w otoczeniu wyrobisk przyścianowych w warunkach geologiczno-górniczych LW Bogdanka SA. Przegląd górniczy, nr 6, 2012.

[6] Herezy t., Zasięg strefy spękań w otoczeniu wyrobiska przyścianowego w trakcie dwóch faz jego istnienia - za frontem pierwszej ściany i przed frontem drugiej ściany. Przegląd górniczy, nr 4, 2015. 
[7] Herezy t., Deformacja wyrobiska przyścianowego w jednostronnym otoczeniu zrobów przed frontem drugiej ściany eksploatacyjnej. Przegląd górniczy, nr 7, 2015.

[8] Herezy t., Relationship between vertical convergence of longwall headings and the pressure increase factor $\xi$ for a powered support section. Unpublished, send to print (Archives of mining science), 2017.

[9] Herezy t., Predicting the vertical convergence of longwall headings basing on the pressure increase factor $\xi$. Unpublished, send to print (Archives of mining science), 2017.

[10] Herezy Ł., Korzeniowski W., Skrzypkowski K., Mathematical model of the work of a hydraulic support for operating pressure. Unpublished, send to print (Mining - Informatics, Automation and Electrical Engineering) 2017.

[11] Hoyer D. (2012): Early warning of longwall of cavities using LVA software. 12th Coal Operators' Conference, University of Wollongong \& the Australasian Institute of Mining and Metallurgy.

[12] Jackobi O., Praxis der Gebirgsbeherrschung. Essen, Verlag Glückauf, 1976.

[13] Konopko W., Kabiesz J., Prędkość postępu ściany a zagrożenie tapaniami i metanem. Materiały Szkoły Eksploatacji Podziemnej, 1996.

[14] Korzeniowski W., Herezy t., Nowoczesna technologia ścianowej eksploatacji pokładu węgla o miąższości 1,6 m kompleksem strugowym. Przegląd górniczy, nr 1-2, 2011.

[15] Korzeniowski W., Herezy t. Krauze K., Rak Z., Skrzypkowski K., Rock mass monitoring based on analysis of powered support response. Wydawnictwa AGH, Cracow, 2013.

[16] Pawlikowski A., Przyczyny asymetrii podporności stojaków sekcji obudowy zmechanizowanej w świetle badań dołowych. Maszyny górnicze, nr 1, 2017.

[17] Płonka M., Load variation of the set of support in the longwall with roof caving. Research reports mining and environment, No 1, 2009.

[18] Płonka M. i Rajwa S., Ocena obciążenia obudowy zmachanizowanej w ścianach kombajnowych i strugowej w oparciu o pomiary ciśneinia w stojakach. Nowe spojrzenie na technikę i technologię eksploatacji cienkich pokładów węgla kamiennego. Bogdanka, 2011.
[19] Rajwa S., Pieszczek M., Guzera J., Selection of powered roof support for wall driven under complex geological-mining conditions in KHW SA, Wieczorek mine. Przegląd górniczy, No 5, 2014.

[20] Rak Z., Utrzymanie chodnika za ściana w trudnych warunkach geologiczo-górniczych na przykładzie kopalni LW Bogdanka $S A-c z e ̨ s ́ c ́$ ll - doświadczenia ruchowe. Przegląd górniczy, nr 1-2, 2011.

[21] Szyguta M., Progress in designing the powered roof support in Poland. Maszyny górnicze, nr 2, 2013.

[22] Prusek S., Empirical-Statistical model of gate roads deformation. Archives of mining science, No 2, 2010.

[23] Trueman R., Lyman G., Cocker A., Longwall roof control through a fundamental understanding of shield-strata interaction. Journal of Rock Mechanics Mining Science, No 46, 2009.

[24] Trueman R., Callan M., Thomas R., Hoyer D., Quantifying the impact of cover depth and panel width on longwall shieldstrata interactions. 10th Coal Operators Conference, 2010.

[25] Trueman R., Thomas R., Hoyer D., Understanding the causes of roof control problems on a longwall face from shield monitoring data-a case study. 11th Underground Coal Operators Conference, University of Wollongong \& the Australasian Institute of Mining and Metallurgy, 2011.

[26] Verma A.K. i Deb D., Analysis of chock shield pressure using finite element method and face stability index. Mining technology, No. 2, 2007.

[27] Verma A.K. i Deb D., Numerical analysis of the interaction between hydraulic powered support and surrounding rock strata at Indian longwall face. The $12^{\text {th }}$ International Conference of International Association for Computer Methods and Advances in Geomechanics. - Goa, India, 2008. 